\title{
Photosynthetic Efficiencies of Rice under Humid and Dry Conditions, as Affected by Varietal Difference in Leaf Areal Nitrogen Content
}

\author{
Shigesaburo Tsunoda and Mithileth K. Singh" \\ Faculty of Agriculture, Tohoku University, Sendai, $\overline{\mathbf{T}} 980$
}

\begin{abstract}
Four rice varieties, Bluebelle, IR 8, Panbira and Sensho, were grown on flooded and dry soil in pots in a glasshouse. Photosynthetic rate $\left(\mathrm{P}, \mathrm{CO}_{2}\right.$ uptake/time), transpiration rate $\left(\mathrm{Tr}, \mathrm{H}_{2} \mathrm{O}\right.$ release/time) and temperature $(\mathrm{T})$ of the second expanded leaf (whole single leaf blade) from the top of the main stem were measured under controlled aeration (40 minutes wet, then 40 minutes dry) and illumination in an air sealed leaf chamber in the laboratory, together with leaf area (LA), fresh weight (FW), dry weight (DM) and nitrogen content $(\mathrm{LN}) . \quad \mathrm{CO}_{2}$ diffusive resistance in the gaseous phase was estimated from $\operatorname{Tr}, \mathrm{T}$ and air humidity, and actual leaf water content after $\mathrm{P}$ and $\mathrm{Tr}$ measurements was estimated from FW and DM. Photosynthetic efficiencies were evaluated on two bases : per unit leaf area $(\mathrm{P} / \mathrm{LA})$ and per unit leaf nitrogen $(\mathrm{P} / \mathrm{LN})$. Four varieties tested showed a marked difference in their leaf density-thickness as indicated by leaf areal nitrogen content (LN/LA). Judging from the leaf nitrogen efficiency in photosynthetic energy conversion $(\mathrm{P} / \mathrm{LN})$, it was concluded that thinly expanded leaves with a lower LN/LA were adapted to humid and densely thick leaves with a higher LN/LA were adapted to dry conditions. With regard to this conclusion, relationships between leaf density-thickness, dehydration avoidance ability, and $\mathrm{CO}_{2}$ diffusive resistance were also discussed.
\end{abstract}

KEY WORDS : Rice, photosynthesis, drought resistance, leaf nitrogen content, leaf density-thickness, adaptation, varietal difference.

\section{Introduction}

Rice, Oryza sativa L., primarily evolved in the humid tropics as a semi-aquatic plant and is adapted to humid and well watered conditions. However, due to limitations of water resources or water management, the area of rice cultivation under upland rainfed conditions is fairly large occupying nearly a sixth of the world's total rice area (DE DatTa, 1975). In most cases of upland rainfed rice, yield stability primarily depends upon the response of rice plants to water dificit. Even in case of lowland irrigated rice, water balance of the plant is apt to be lost under dry atmospheric conditions.

Iyama and Murata (1961) pointed out that the ability to keep water in the leaf blade against a moisture stress was a main factor determining specific differences in photosynthetic response to drought, and that the rice was the weakest in this ability among crop species observed including barley, wheat and soybean. O'Toole and Moy a (1978) observed significant differences among rice genotypes for maintenance of relatively high leaf water potential against drought and a close relationship between the leaf water potential and visual scoring of plant symptoms in response to drought. These observations indicate that the ability to keep a higher water content or potential against drought, i.e. the ability of dehydration avoidance according to Levirt (1972), has an important bearing on the drought resistance of rice. Several morpho-physiological plant properties such as

Received May 13, 1985.

1) Present address : P. G. Department of Botany, S. C. College, Jamshedpur, Bihar, India 831001 
high root/shoot or high deep-root/shoot ratio (O'Toole and $C_{R U Z}, .1980$ ), large size xylem vessels (Tsunoda, 1984), higher cuticular resistance (Yoshida and DE, LOS ReYes, 1976), lesser stomatal frequency (Yoshida and ONo, 1978), stomatal closing (IRRI, 1974) and glabrous broad leaves (Tsunoda and Kittaka, 1952) have been investigated regarding the dehydration avoidance of rice varieties.

In the present investigation we dealt with the significance of genotypic differences in leaf density-thickness as a factor determining the dehydration avoidance ability and the adaptability to humid or dry conditions in rice varieties. In wheat as well as in soybean similar studies have been carried out in our laboratory (SingH and Tsunoda, 1978; KIsh'TANi and TSUNODA, $1981 ; 1982)$ and revealed that thinly expanded leaves were adapted to humid conditions and densely thick leaves coupled with a restriction of leaf area were adapted to dry conditions. The same trend was observed in this study with rice, in which differences in leaf density-thickness were indicated by the differences in leaf nitrogen content per unit leaf area as in the previous studies with wheat and soybean. Differences in adaptability to humid or dry conditions were also evaluated by varietal differences in photosynthetic response of their leaves to humid and dry conditons as in our previous studies with wheat and soybean.

\section{Materials and Methods}

Four cultivars, Bluebelle, IR 8, Panbira and Sensho, of rice (Oryza sativa) were selected for the present study. The former three varieties were also included in an IBP (International Biological Program) project at this laboratory concerning the stability of leaf photosynthesis against high and low air temperatures (Kishitani and Tsunoda, 1974). Sensho is an upland rice variety introduced in Japan about 90-100 years ago from Korea or Taiwan (Tsunoda, 1975). Bluebelle is a lowland variety of the South of the U.S.A. grown under relatively dry atmospheric conditions as compared with the climate of the rice growing rainy season in the southeastern Asia, the homeland of rice. IR 8 is a lowland variety released by IRRI (International Rice Research Institute) for the southeastern Asian countries, a semi-dwarf adapted to controlled irrigation. Panbira is a lowland landrace of Bangladesh.

Plants sown from seed at the end of April were grown singly in pots $(20 \mathrm{~cm}$ height by $15.5 \mathrm{~cm}$ diameter) containing river clay-silt in a glasshouse. A nutrient solution (47 $\mathrm{g}$ ammonium sulphate, $10 \mathrm{~g}$ sodium phosphate and $12 \mathrm{~g}$ potassium chloride per litre) was supplied weekly $10-15 \mathrm{~m} l$ per pot according to the stage of plant growth. The water level was kept $1-2 \mathrm{~cm}$ above the surface of the soil. From the beginning of July, water supply to 5 pots of each variety was controlled so as to create a soil moisture tension of 65 cbar gradually within 3 weeks and to keep this level thereafter monitored by a tensiometer of each pot at the $10 \mathrm{~cm}$ depth, while other 5 pots of each variety were maintained continueously in flooded conditions. The experimental layout in the glasshouse was a split-plot design with five replications in which each replicated plot was firstly devided into two subplots (each one row) of flooded and dry soil treatment, the pots of four varieties were randomly arranged in each subplot. The observation of plant properties was also carried out following this pot arrangement. 
During the last week of July, photosynthetic rate (P), transpiration rate ( $\mathrm{Tr}$ ) and temperature of the second expanded leaf from the top of the main stem were observed under controlled aeration and illumination in an acrylic air sealed leaf chamber in the laboratory adjacent to the glasshouse, together with leaf area (LA), leaf water content $\left(\mathrm{W}_{\mathrm{act}}\right)$ and leaf nitrogen content $(\mathrm{LN})$. The air controlled at $30 \pm 1^{\circ} \mathrm{C}$ was passed through the leaf chamber $(3.2 \mathrm{~mm}$ interior thickness, $10.2 \mathrm{~mm}$ width) at a rate of 1 litre per minute. The relative humidity of the air entering the leaf chamber was firstly controlled within a range of $68 \pm 3 \%$ (around $13.6 \mathrm{mbar}$ in vapor pressure dificit) for 40 minutes, then within a range of $23 \pm 2 \%$ (around $32.7 \mathrm{mbar}$ in vapor pressure deficit) for next 40 minutes, by passing the air on the water table in a chamber or through silica gel in a tube. Irradiation on the surface of the leaf chamber was 1.09 cal $\mathrm{cm}^{-2} \mathrm{~min}^{-1}\left(4.58 \mathrm{~J} \mathrm{~cm}^{-2} \mathrm{~min}^{-1}\right)$. The light source was six $500 \mathrm{~W}$ incandescent lamps and large ( $25 \mathrm{~cm}$ thickness) acrilic chamber with running water was placed in between the light source and the leaf chamber to absorb the infrared radiation. $\mathrm{P}$ and $\operatorname{Tr}$ were estimated by reading the difference of $\mathrm{CO}_{2}$ and $\mathrm{H}_{2} \mathrm{O}$ concentration between the incoming and outgoing air of the leaf chamber with an infrared gas analyser (Hitachi-Horiba model ASSA-2) and two sets of dry and wet bulb thermometers. Leaf temperature was recorded by a thermister to compute the $\mathrm{CO}_{2}$ diffusive resistance in the gaseous phase $\left(\mathrm{r}_{\mathrm{a}}+\mathrm{r}_{\mathrm{s}}\right)$ according to formula of GaAstra (1959). Following the $\mathrm{P}$ and $\mathrm{Tr}$ measurements, the leaf was cut off, and its area (LA) and fresh weight (FW) were measured. Then, the leaf was placed in an air blast of $80^{\circ} \mathrm{C}$ to determine dry matter content (DM) and actual water content $\left(W_{\text {act }}\right)$ when the leaf was cut off. In the dry matter, nitrogen content (LN) was measured by the Kjeldahl method. Mean values of five replicated observations are presented in this paper, and standard errors of estimate of mean values (s. e. mean) are also shown in Tables 1 and 2 .

On the same stage leaf sampled from another tall stem chlorophyll content (Chl) was also measured by method of ARNON (1949). However, due to technical mistakes data are missing for the plants grown on dry soil (Table 2).

\section{Results}

Photosynthetic rate per unit leaf area-light use efficicency: When grown on flooded soil (Fig. 1-A), photosynthetic rate per unit leaf area (P/LA) was highest in Bluebelle and lowest in Panbira, under wet air as well as dry air condition. Sensho and IR 8 showed a medium value, although IR 8 decreased the rate for a time under dry air to the level that of Panbira (Fig. 1-A). P/LA was decreased by dry soil treatment. The suppression of $\mathrm{CO}_{2}$ uptake by dry soil treatment was, however, not so marked in Bluebelle, while it was most remarkable in IR 8 (Fig. 1-B).

Photosynthetic rate per unit leaf nitrogen-Leaf nitrogen efficiency : Photosynthetic efficiency evaluated on the basis of unit leaf nitrogen ( $P / L N)$ was highest in IR 8 , followed by Panbira and then Sensho, and lowest in Bluebelle, when the plants were grown on flooded soil (Fig. 2-A). Whereas, when grown on dry soil of 65 cbar water tension, $\mathrm{P} / \mathrm{LN}$ was higher in Sensho and Panbira, followed by Bluebelle, and lowest in IR 8 (Fig. 2-B). Difference in $\mathrm{P} / \mathrm{LN}$ between Bluebelle and the top group of Sensho and Panbira 


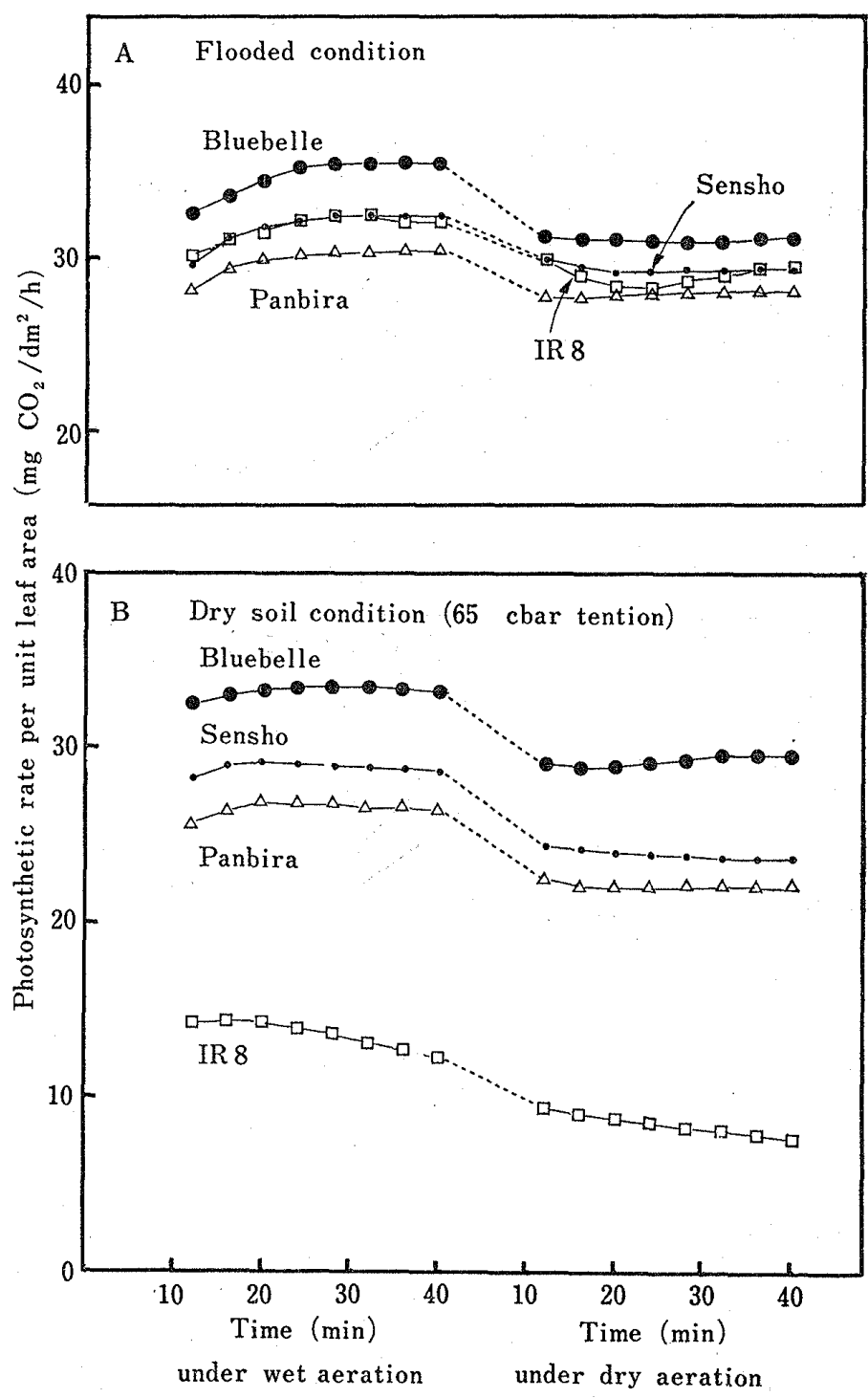

Fig. 1. Light use efficiency-photosynthetic rate per unit leaf area $(\mathrm{P} / \mathrm{LA})$ of four rice varieties; Bluebelle ( Sensho ( ), Panbira $(\triangle)$ and IR $8(\square)$.

was relatively marked under wet air, however it became little under dry air (Fig. 2-B).

$\mathrm{CO}_{2}$ diffusive resistance of the leaf: As seen in Figs. 1 and 2, P reached a stable state at least after 40 minutes under a given condition, except for IR 8 grown under dry soil condition. Table 1 shows the mean values of photosynthetie rate per unit leaf area $(\mathrm{P} / \mathrm{LA})$, transpiration rate per unit leaf area $(\mathrm{Tr} / \mathrm{LA})$ and $\mathrm{CO}_{2}$ diffusive resistance ( $\mathrm{r}$ ) of the leaf, measured after 40 minutes under a given condition. Diffusive resistance ( $r$ ) was increased by dry soil treatment. The increase in $r$ by dry soil treatment, however, was slight in Bluebelle. On the contrary, it was very marked in IR 8 . Beside, Sensho, grown on flooded soil, tended to show a little higher diffusive resistance as compared with other varieties grown on the same flooded soil (Table 1).

Water, dry matter, nitrogen and chlorophyll content: Actual leaf water content per unit leaf area $\left(\mathrm{W}_{\mathrm{act}} / \mathrm{LA}\right)$ as well as per unit leaf dry matter $\left(\mathrm{W}_{\mathrm{act}} / \mathrm{DM}\right)$ measured after the gas exchange ( $P$ and $T r$ ) measurement under 40 minutes wet and 40 minutes dry air condition was highest in Bluebelle, followed by Sensho, and lowest in the other two 


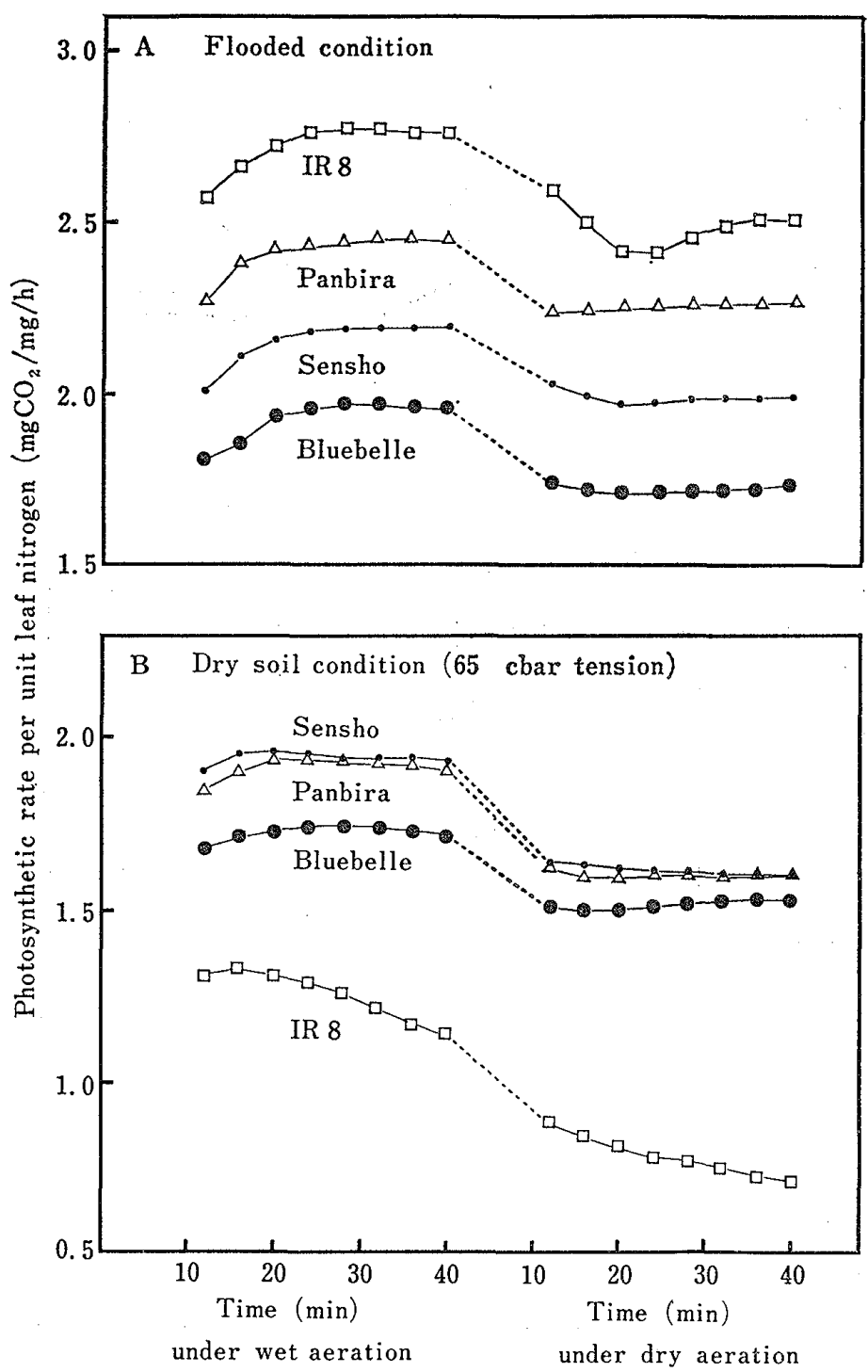

Fig. 2. Leaf nitrogen efficiency-photosynthetic rate per unit leaf nitrogen (P/LN) of four rice varieties; Bluebelle ( Sensho ( $)$, Panbira $(\triangle)$ and IR $8(\square)$.

varieties, Panbira and IR 8 . Especially, IR 8 showed the lowest leaf water content when grown on dry soil (Table 2). Leaf areal nitrogen content (LN/LA) was highest in Bluebelle, followed by Sensho and then Panbira, and lowest in IR 8. The difference in LN/LA between Bluebelle and IR 8 was fairly large. It in the latter variety was around 60 percent that of the former (Table 2). Chlorophyll content (Chl) was measured only for the plants grown on flooded soil. The level of Chl/LA was almost parallel to that of LN/LA among three varieties of Bluebelle, Sensho and Panbira. However, IR 8 showed a higher Chl/LA for its low LN/LA as compared with other varieties (Table 2).

\section{Discussion}

Leaf photosynthesis efficiency was evaluated in the present study on two different bases; per unit leaf area (P/LA, Fig. 1) and per unit leaf nitrogen (P/LN, Fig. 2). P/LA is, of course, an important parameter which shows the efficiency of photosynthetic energy conversion of light received by the leaf. On the other hand, P/LN is also 
Table 1. Photosynthetic rate per unit leaf area $(\mathrm{P} / \mathrm{LA})$, transpiration rate per unit leaf area $(\mathrm{Tr} / \mathrm{LA})$ and $\mathrm{CO}_{2}$ diffusive resistance $(r)$ of four rice varieties measured after 40 minutes under a given condition (Mean values of five observations with s.e. mean)

\begin{tabular}{|c|c|c|c|c|c|}
\hline Variety & Soil & $\begin{array}{l}\text { Pho } \\
\text { per } \\
\text { Air }\end{array}$ & $\begin{array}{l}\text { osynthetic rate } \\
\text { unit leaf area } \\
\mathrm{mg} \mathrm{CO} / \mathrm{dm}^{2} / \mathrm{h} \\
(\mathrm{P} / \mathrm{LA})\end{array}$ & $\begin{array}{c}\text { Transpiration rate } \\
\text { per unit leaf area } \\
\text { mg } \mathrm{H}_{2} \mathrm{O} / \mathrm{cm}^{2} / \mathrm{h} \\
(\mathrm{Tr} / \mathrm{LA})\end{array}$ & $\begin{array}{l}\mathrm{CO}_{2} \text { diffusive } \\
\text { resistance } \\
\text { sec/cm } \\
(\mathrm{r})\end{array}$ \\
\hline \multirow[t]{4}{*}{ Bluebelle } & Flooded & Wet & $35.6 \pm 2.0$ & $23.4 \pm 2.0$ & $0.280 \pm 0.015$ \\
\hline & & Dry & $31.5 \pm 1.7$ & $54.8 \pm 2.0$ & $0.267 \pm 0.009$ \\
\hline & Dry & Wet & $33.3 \pm 1.7$ & $25.6 \pm 1.3$ & $0.287 \pm 0.018$ \\
\hline & & Dry & $29.6 \pm 1.5$ & $53.1 \pm 2.5$ & $0.289 \pm 0.019$ \\
\hline \multirow[t]{4}{*}{ Sensho } & Flooded & Wet & $32.6 \pm 2.2$ & $23.8 \pm 1.6$ & $0.304 \pm 0.034$ \\
\hline & & Dry & $29.5 \pm 2.0$ & $53.7 \pm 3.6$ & $0.271 \pm 0.029$ \\
\hline & Dry & Wet & $28.8 \pm 1.9$ & $23.7 \pm 3.6$ & $0.320 \pm 0.025$ \\
\hline & & Dry & $23.8 \pm 1.6$ & $46.6 \pm 3.1$ & $0.338 \pm 0.025$ \\
\hline \multirow[t]{4}{*}{ Panbira } & Flooded & Wet & $30.5 \pm 2.4$ & $22.7 \pm 1.8$ & $0.271 \pm 0.013$ \\
\hline & & Dry & $28.2 \pm 2.3$ & $53.5 \pm 4.3$ & $0.246 \pm 0.004$ \\
\hline & Dry & Wet & $26.5 \pm 1.9$ & 23. $0 \pm 1.6$ & $0.314 \pm 0.017$ \\
\hline & & Dry & $22.2 \pm 1.6$ & $48.2 \pm 3.5$ & $0.329 \pm 0.025$ \\
\hline \multirow[t]{4}{*}{ IR 8} & Flooded & Wet & $32.4 \pm 2.8$ & $26.6 \pm 2.3$ & $0.282 \pm 0.021$ \\
\hline & & Dry & $29.5 \pm 2.5$ & $56.7 \pm 4.8$ & $0.251 \pm 0.018$ \\
\hline & Dry & Wet & $12.5 \pm 1.1$ & $16.0 \pm 1.5$ & $0.572 \pm 0.037$ \\
\hline & & Dry & $7.8 \pm 0.7$ & $25.0 \pm 2.3$ & $0.761 \pm 0.117$ \\
\hline
\end{tabular}

important for the plant growth, as stated by TAKano and Tsunoda (1971). When the amount of total leaf nitrogen is limited for a plant population, high $\mathrm{P} / \mathrm{LN}$ may bring about a high relative growth rate of the plant population. Further, TAKano and Tsunoda (1971) observed a positive correlation between P/LA and LN/LA and a negative correlation between $\mathrm{P} / \mathrm{LN}$ and $\mathrm{LN} / \mathrm{LA}$ among rice varieties.

In the present experiment, LN/LA was highest in Bluebelle (Table 2), and this variety showed the highest P/LA among varieties in all conditions tested (Fig. 1). On the other hand, this variety Bluebelle showed the lowest $\mathrm{P} / \mathrm{LN}$ when the plants were grown on flooded soil (Fig. 2-A). IR 8 showed the highest P/LN with the lowest LN/LA when grown on flooded soil (Fig. 2-A and Table 2). These results agree with those reported by TAKano and Tsunoda (1971). However, IR 8 showed the lowest $\mathrm{P} / \mathrm{LN}$ among varieties

Table 2. Water, dry matter, nitrogen and chlorophyll content per unit leaf area

\begin{tabular}{llccccc}
\hline Variety & Soil & $\begin{array}{c}\text { Water } \\
\text { mg/dm } \\
\left(\mathrm{W}_{\mathrm{act}} / \mathrm{LA}\right)\end{array}$ & $\begin{array}{c}\text { Dry matter } \\
\mathrm{mg} / \mathrm{dm}^{2} \\
(\mathrm{DM} / \mathrm{LA})\end{array}$ & $\begin{array}{c}\text { Nitrogen } \\
\left(\mathrm{W}_{\text {act }} / \mathrm{DM}\right)\end{array}$ & $\begin{array}{c}\text { Chlorophyll } \\
\mathrm{mg}^{2} / \mathrm{dm}^{2} \\
(\mathrm{~N} / \mathrm{LA})\end{array}$ & $\begin{array}{c}\mathrm{mg}^{2} \\
(\mathrm{Chl} / \mathrm{LA})\end{array}$ \\
\hline Bluebelle & Flooded & $1172 \pm 28$ & $533 \pm 13$ & 2.20 & $18.1 \pm 1.2$ & $4.38 \pm 0.12$ \\
& Dry & $1067 \pm 22$ & $492 \pm 12$ & 2.17 & $19.3 \pm 1.0$ & - \\
Sensho & Flooded & $854 \pm 29$ & $458 \pm 20$ & 1.86 & $14.8 \pm 0.6$ & $3.50 \pm 0.06$ \\
& Dry & $812 \pm 25$ & $443 \pm 17$ & 1.83 & $14.9 \pm 0.3$ & - \\
Panbira & Flooded & $659 \pm 28$ & $389 \pm 24$ & 1.69 & $12.4 \pm 0.5$ & $3.07 \pm 0.14$ \\
& Dry & $681 \pm 22$ & $396 \pm 11$ & 1.72 & $13.9 \pm 0.7$ & - \\
& Flooded 8 & $669 \pm 31$ & $400 \pm 17$ & 1.67 & $11.7 \pm 1.1$ & $4.03 \pm 0.26$ \\
& Dry & $633 \pm 23$ & $396 \pm 26$ & 1.60 & $11.0 \pm 0.9$ & - \\
\hline
\end{tabular}


with the lowest LN/LA when the plants were grown on dry soil (Fig. 2-B), accompanying a sharp increase in $\mathrm{CO}_{2}$ diffusive resistance $(r)$ and a lower water content per unit leaf area $\left(W_{\text {act }} / \mathrm{LA}\right)$ as well as per unit leaf dry matter $\left(W_{\mathrm{act}} / \mathrm{DM}\right)$ (Tables 1 and 2 ). It seems reasonable to infer that the sharp drop of $\mathrm{P}$ (P/LA as well as $\mathrm{P} / \mathrm{LN}$ ) in IR 8 by dry soil treatment was brought about by a sharp increase in $\mathrm{r}$ (Table 1) which was caused by stomatal closing due to a lower leaf water content ( $\mathrm{W}_{\text {act }} / \mathrm{LA}$ and $\mathrm{W}_{\mathrm{act}} / \mathrm{DM}$, Table 2) of this variety grown on dry soil. Further, thinly expanded leaves of this variety with a lower LN/LA may have a bearing to the lowered leaf water content $\left(\mathrm{W}_{\mathrm{act}} / \mathrm{LA}\right.$ and $\mathrm{W}_{\mathrm{act}}$ ) DM, Table 2) through reduction of leaf water storage capacity and enlargement of transpiring leaf surface.

As mentioned in the Introduction, Singh and Tsunoda (1978) and Kishitani and Tsunoda (1981) with wheat and Kishitani and Tsunoda (1982) with soybean stated that thinly expanded leaves with a lower LN/LA were adapted to humid situations and densely thick leaves were adapted to dry conditions, judging from the nitrogen efficiency in leaf photosyhthesis $(\mathrm{P} / \mathrm{LN})$. The same trend was observed in the present study with rice varieties. When the plants were grown on flooded soil, the lower the LN/LA, the higher the P/LN among varieties observed (Table 2 and Fig. 2-A). When the plants were grown on a dry soil condition of 65 cbar soil moisture tension, varieties exhibiting an intermediate LN/LA, Sensho and Panbira, showed the highest P/LN (Table 2 and Fig. 2-B). Reduction of $\mathrm{P} / \mathrm{LN}$ due to dry soil treatment was most slight in Bluebelle exhibiting the highest LN/LA and most drastic in RI 8 exhibiting the lowest LN/LA. The difference became especially marked when the dry soil treatment was combined with dry aeration (Fig. 2).

We may conclude that thinly expanded leaves with a lower LN/LA are adapted to humid conditions and densely thick leaves with a higher LN/LA are adapted to dry conditions also in rice, judging from their leaf nitrogen efficiency in photosynthetic energy conversion, as in wheat (Singh and Tsunoda, 1978 ; Kishitani and Tsunoda, 1981) and soybean (Kishitani and Tsunoda, 1982). Optimum leaf density-thickness as indicated by LN/LA is different according to the situations of the soil and the air which are related to water supply to and water release from the plants.

It should be noted here, however, that optimum leaf density-thickness as indicated by LN/LA depends also on the levels of nitrogen supplied to the plants (Tsunoda, 1959) as well as on the intensity of radiation given to the plants (Kishitani et al. 1972). Further, plant properties other than leaf density-thickness are also concerned with the dehydration avoidance and the plant's adaptability to humid and dry conditions, as briefly reviewed in the Introduction. Therefore, actual optimum leaf density-thickness as indicated by LN/LA should be determined taking into consideration these environmental and plant side factors.

\section{Acknowledgement}

The second author was invited to Japan by the Japan Socity for the Promotion of Science, to which we are deeply grateful. 


\section{Literature Cited}

ARNON, D. I. 1941. Copper enzyme in isolated chloroplasts. Pl. Physiol. 24:1 15.

DE DATTA, S.K. 1975. Upland rice around the world. In "Major research in upland rice", IRRI, Los Baños, Philippines. 2 11.

GAARSTRA, P. 1969. Photosynthesis of crop plants as influenced by light, carbon dioxide, temperature, and stomatal diffusion resistance. Meded. Landbouwhogesch., Wageningen 59: 1 68.

IRRI (International Rice Research Institute) 1974. Screening for drought resistance. In "Annual report for 1973", IRRI, Los Baños, Philippines. 53 55 .

IYAMA, I. and Y. MURATA 1961. Studies on the photosynthesis in upland field crops. II. Relationships between the soil moisture and photosynthesis of some upland crops and rice plant. Proc. Crop Sci. Soc. Japan 29:350 352.

LEviTT, J. 1972. Response of plant to environmental stress, $697 \mathrm{pp.} \mathrm{Academic} \mathrm{Press,} \mathrm{New} \mathrm{York.}$

KISHITANI, S., Y. TAKANO and S. TSUNODA 1972. Optimum leaf-areal nitrogen content of single leaves for maximizing the photosynthesis rate of leaf canopies : a simulation in rice. Japan. J. Breed. $22: 1 \sim 10$.

- and S. TSUNODA 1974. Effect of low and high temperature pretreatment on leaf photosynthesis and transpiration in cultivars of Oryza sativa. Photosynthetica $8: 161 \sim 167$.

- 1981 . Physiological aspects of domestication in diploid wheat. Euphytica 30 : $247 \sim 252$.

- 1982. Leaf thickness and response of leaf photosynthesis to water stress in soybean varieties. Euphytica $31: 657 \sim 664$.

O'TOOLE, J.C. and T.B. MOYA 1978. Genotypic variation in maintenance of leaf water potential in rice. Crop Sci. $18: 873 \sim 876$.

- and R. T. CRUZ 1980. Response of leaf water potential, stomatal resistance and leaf rolling to water stress. Pl. Physiol. 65: 428 432.

SINGH, M. K. AND S. TSUNODA 1978. Photosynthetic and transpirational response of a cultivated and a wild species of Triticum to soil moisture and air humidity. Photosynthetica $12: 280 \sim 283$.

TAKANO, Y. and S. TSUNODA 1971. Curvilinear regression of the leaf photosynthetic rate on leaf nitrogen content among strains of Oryza species. Japan. J. Breed. $21: 69 \sim 76$.

TSUNODA, S. and A. KITTAKA 1952. Occurence of withered and completely sterile panicles in rice plants attacked by typhoon, with special reference to varietal resistance. II. Some characters of resistive and sensitive varieties. Proc. Crop Sci. Soc. Japan $21: 185 \sim 186$.

1959. A developmental analysis of yielding ability in varieties of field crops. II. The assimilation-system as affected by the form, direction and arrangement of single leaves. Japan. J. Breed. $9: 237 \sim 244$.

1975. Line grouping of Japanese upland rice varieties (in Japanese). Japan. J. Breed. 25: $121 \sim 128$.

1984. Adjustment of photosynthetic structures in three steps of rice evolution. In "Biology of rice" TSUNODA, S. and N. TAKAHASHI (eds.), Japan Sci. Soc. Press, Tokyo/Elsevier, Amsterdam. $89 \sim 115$.

YOSHIDA, T. and T. ONO 1978. Environmental differences in leaf stomatal frequency of rice. Japan. J. Crop Sci. $47: 506 \sim 514$.

YOSHIDA, S. and E. DE LOS REYES 1976. Leaf cuticular resistance of rice varieties. Soil Sci. Pl. Nutr. $22: 95 \sim 98$. 
湿潤および乾燥条件下に和けるイネの光合成効率と 葉面積当たり葉窒素含量の品種間差異

\author{
角田重三郎・M.K. SINGH \\ （東北大学農学部，仙台市，广 980）
}

葉面積当たりの葉窒素の多い葉を持つ品種，葉窒素量を指標とした場合の. Density-thickness（密度を加味 した“厚さ”）の大きな品種は乾燥条件に適し，葉面積当たりの葉窒素の少ない葉を持つ品種，単位葉窒素で “薄く”(密度を加味した厚さで薄〉)広く葉を展開する品種は湿潤条件に適することが，コムギおよびダイズ で指摘されている(Singh and Tsunoda, 1978 ; Kishitani and TsunOda, 1981；1982). 同様の傾向が，1 ネについて本研究で認められた。

イネ(Oryza sativa) の 4 栽培品種, Bluebelle, IR 8，Panbira 打よび戦捷を供試した. Bluebelle は米国 南部の水稲で, イネの原産地の東南アジアの雨季の稻作期の気候に比べた場合, 比較的乾燥した大気条件下で 作られる.IR 8 は国際稲研究所で育種された東南アジア向けの水稲で, 制御された灌溉汇適する半矮性の品種 である. Panbira、はバングラデシュの在来の水稲である. 戦捷は 90-100 年前に台泖あるいは朝鮮から日本に

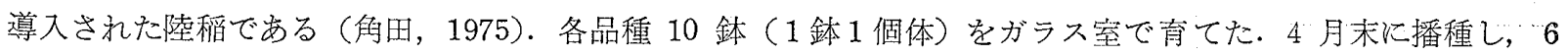
月始めまで全鉢湛水した．その後 5 錸への灌水を制限して 3 週後からは土畩の水張力 $65 \mathrm{cbar}$ を維持するよう にし，他の 5 鉥は引き続き湛水した． 6 月の最終の週に，主莰の上から 2 番目の展開葉をエアーシールされた アクリル製葉室に挿入し，その光合成速度 $(\mathrm{P})$, 蒸散速度 $(\mathrm{Tr})$, 温度 $(\mathrm{T})$ を通気之照明を制御して測った。 始めの 40 分は湿った空気（菜室の入口で温度 $30 \pm 1^{\circ} \mathrm{C}$, 関係濕度 $63 \pm 3 \%$ ) 次の 40 分乾いた架気 (30 $\pm 1^{\circ} \mathrm{C}, 23 \pm 2 \%$ ) を通気した。 その後葉を切断し, 葉面積 (LA), 葉の水分含量 (Wact), 畭物量 (DM), 窒 素含量 (LN) を測定した. $\mathrm{Tr}, \mathrm{T}$ なぞから葉の $\mathrm{CO}_{2}$ 拡散抵抗も推定した。各計測は各品種 5 個体について行 い，図表には平均値を示した。

光合成効率を単位葉筀素当たり $(\mathrm{P} / \mathrm{LN})$ で比較すると，湛水下で生育させた場合（Fig. 2-A）には，単位葉 窒素で “薄く”広く葉を展開する IR 8 (Table 2 参照) が最高の効率を示した. 一方乾土 (水張力 65 cbar)

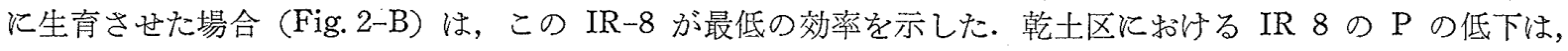
葉の $\mathrm{CO}_{2}$ 拡散抵抗の增大を伴って扔り (Table 1), “薄く”広く展開された葉が乾燥条件下で葉の水分欠乏を おこし (Table 2 参照), 気孔が閉じたものと推定できる. 葉面積当たりの葉窒素量 (LN/LA)を指標とした葉 の “厚さ” “薄さ”の最適值は, 植物への水の供給と植物からの水の逸出飞関係している土壤と空気の状態によ ると言光る. 但し, 最適の葉面積当たりの葉窒素量 (LN/NA) はまた植物への窒素の供給 (TSUNODA, 1959), さらにまた植物へ与えられる光の強度 (KISHITANI et al., 1972) によっても異なる。窒素の供給量が多け机ば 少ないときよりる，そして光強度が高いときは低いときよりる，葉面積当たり葉空素量 (LN/LA) の多い葉が 適応する。な执また，葉の “厚さ” “薄さ” 以外の植物の諸特性が乾燥条件下に拉ける植物の水平衡に関係して いる. それ故, 葉面積当たりの葉筑量 (LN/LA)を指標とした葉の最適の Density-thickness はこれらの環境 側抒よび植物側の諸要因を考慮に入れて決定されるべきものである. 